\title{
Biodegradation of atrazine by Arthrobacter sp. C3, isolated from the herbicide-contaminated corn field
}

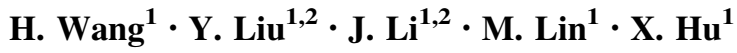

Received: 2 August 2014/Revised: 17 June 2015/Accepted: 7 July 2015 / Published online: 4 August 2015

(C) Islamic Azad University (IAU) 2015

\begin{abstract}
The $s$-triazine herbicide, atrazine, has been well acknowledged as an important source causing contamination of soil, water, and sediment. Functional bacteria are one of the critical candidates for removing residual atrazine from contaminated environments. Here, seven bacterial strains showing atrazine-degrading ability were isolated from long-term atrazine-contaminated corn field and identified based on 16S rRNA gene sequencing. Among these bacterial isolates, a bacterium, later designated as Arthrobacter sp. C3, was found to be capable of completely degrading $25 \mathrm{mg} / \mathrm{l}$ atrazine. The high-performance liquid chromatography-mass spectrometry (HPLC-MS) analysis indicated that the atrazine was dechlorinated to hydroxyatrazine, a non-phytotoxic compound. The functional gene, $t r z \mathrm{~N}$, which participates in the first step of atrazine degradation was successfully amplified and showed high similarity to the known $\operatorname{trz} \mathrm{N}$ genes from different bacterial genera. Based on the HPLC-MS and the functional gene analysis, the functional bacterium $\mathrm{C} 3$ was speculated to degrade atrazine via dechlorination, which detoxified the herbicide. This study suggested a great potential of Arthrobacter sp. C3 to be used in indigenous bioremediation of atrazine in field.
\end{abstract}

H. Wang and Y. Liu have contributed equally to this work.

Electronic supplementary material The online version of this article (doi:10.1007/s13762-015-0860-8) contains supplementary material, which is available to authorized users.

$\mathrm{X} . \mathrm{Hu}$

xkhu@yic.ac.cn

1 Yantai Institute of Costal Zone Research, Chinese Academy of Sciences, Yantai 264003, China

2 University of Chinese Academy of Science, Beijing 100049, China
Keywords Atrazine - Biodegradation - Arthrobacter . Hydroxyatrazine

\section{Introduction}

Driven by the increasing use of herbicide, contamination caused by this kind of pesticide has received public and scientific attention. Atrazine (2-chloro-4-ethylamino-6-isopropylamino-1,3,5-triazine), an s-triazine herbicide, is extensively used in cropped soils to control weeds, especially during production of corn (Topp et al. 2000). For its high mobility and relatively long half-life, atrazine has been proved to easily contaminate different habitats, including soil, surface water, and ground water (Rousseaux et al. 2001). The residual of atrazine in environment not only could damage the following crops in the field and reduce populations of other organisms, but also has severe impacts on human health. The herbicide was reported as an endocrine-disrupting chemical, which could cause birth defects, reproductive tumors, and weight loss (Fernández et al. 2013). Thus, it is critical to eliminate residual atrazine from environment.

Bioremediation is the technique utilizing biological organisms to aid in removal of hazardous substances from a polluted area (Head et al. 2006; Louisa Wessels 2010). Microorganisms, especially bacteria, are key players in the process of bioremediation of most organic pollutants (Wang et al. 2009a, b). Atrazine could be biodegraded by either single functional bacterium or microbial consortia (Tortella et al. 2013; Yanze-Kontchou and Gschwind 1994). A number of bacterial strains affiliated into different genus, Pseudomonas, Rhizobium, Acinetobacter, Arthrobacter, and Pseudaminobacter, have been successfully isolated from agricultural soils, industrial wastewater, and other atrazinepolluted environment (Cai et al. 2003; Topp et al. 2000; Singh 
et al. 2004; de Souza et al. 1998; Bouquard et al. 1997). For instance, Singh et al. (2004) isolated an Acinetobacter strain which could degrade atrazine as high as $250 \mathrm{ppm}$ from a soil heavily contaminated with atrazine. The bacterium could utilize atrazine as a carbon, but not as a nitrogen source. On the other side, microbial consortium could be constructed by applying different functional isolates in the same process. Two bacterial isolates, Klebsiella sp. A1 and Comamonas sp., isolated from the sewage of a pesticide mill were combined as a microbial consortium for bioremediation of atrazine (Yang et al. 2010). A high atrazine-mineralizing efficiency was detected with $83.3 \%$ mineralization of $5 \mathrm{~g} / \mathrm{l}$ atrazine in $24 \mathrm{~h}$. This should be attributed to the co-metabolic process of the two functional bacteria.

Even though dramatic improvements have been achieved, it is still necessary for isolating more efficient atrazine-degrading bacteria, given the large-scale use of atrazine and its toxicity. The aims of this study are (1) to isolate and identify atrazine-degrading bacteria and (2) to investigate the mechanisms of atrazine degradation and functional genes involved in the process.

\section{Materials and methods}

\section{Sample collection}

Soil samples were collected from a long-term (twice a year for at least 3 years) atrazine-sprayed corn field in east of China (N: 37.185926, E: 122.255335). Samples were collected in the $5-15 \mathrm{~cm}$ layer by removing surface soil. Samples used for isolating atrazine-degrading bacteria were kept in a cooler with insulation and ice packs, and transported to the laboratory in $2 \mathrm{~h}$ for further analysis.

\section{Isolation and identification of atrazine-degrading bacterium}

Immediately after samples were transferred to the laboratory, ten grams of soil samples and $25 \mathrm{mg} / \mathrm{l}$ (final concentration) of atrazine (Dr. Ehrenstorfer GmbH, Germany) were co-incubated in $100 \mathrm{ml}$ mineral solution $\left(7.01 \mathrm{mM} \mathrm{K}_{2} \mathrm{HPO}_{4}\right.$, $2.94 \mathrm{mM} \quad \mathrm{KH}_{2} \mathrm{PO}_{4}, \quad 0.81 \mathrm{mM} \quad \mathrm{MgSO}_{4} \cdot 7 \mathrm{H}_{2} \mathrm{O}, \quad 0.18 \mathrm{mM}$ $\mathrm{CaCl}_{2}, 1.71 \mathrm{mM} \mathrm{NaCl}$ ) for 7 days with shaking at $180 \mathrm{rpm}$ at $30{ }^{\circ} \mathrm{C}$. One $\mathrm{ml}$ of liquid culture was tenfold serially diluted to $10^{-7}$, and $100 \mu \mathrm{l}$ aliquots of each dilution was spread onto mineral agar which was prepared by adding $15 \%$ agar into mineral solution with $25 \mathrm{mg} / \mathrm{l}$ of atrazine. The plates were incubated at $30{ }^{\circ} \mathrm{C}$ for $48 \mathrm{~h}$. Morphologically different colonies were streaked on mineral agar for isolation. Single colonies of each isolate were transferred to $10 \mathrm{ml}$ of mineral solution to test the biodegrading capability. Yeast extract (1\%o) was supplemented as carbon and nitrogen source.
$1.8 \mathrm{ml}$ of liquid culture was used for DNA extraction, while $1 \mathrm{ml}$ of the residual was cryopreserved at $-80{ }^{\circ} \mathrm{C}$ with $1 \mathrm{ml}$ of $60 \%$ glycerol. DNA was extracted from liquid cultures using the UltraClean microbial DNA isolation Kit (MoBio Laboratories, Carlsbad, CA). The 16S rRNA gene from each isolate was PCR amplified and sequenced using universal primers $27 \mathrm{~F}$ and $1492 \mathrm{R}$ as described previously (Enticknap et al. 2006). 16S rRNA gene sequences from isolates were analyzed using the BLASTn tool at the National Center for Biotechnology Information (NCBI) website. Isolates were presumptively identified according to the identity of the closest cultured relative in the top BLAST hits.

\section{Effect of exogenous carbon and nitrogen on the growth of the functional bacterium}

Different carbon and nitrogen sources were added into the mineral solution mentioned above to assess the requirements for the growth of the functional bacterium. Treatments were as follows: mineral solution amended with (1) yeast extract (1\%, w/v) which could supply both carbon and nitrogen sources; (2) glucose (1\%, w/v) as carbon source; (3) $\mathrm{NH}_{4} \mathrm{NO}_{3}(1 \%$, w/v) as nitrogen source; and (4) no additional carbon and nitrogen sources (negative control). $25 \mathrm{mg} / \mathrm{l}$ of atrazine was added to all treatments and co-incubated for $48 \mathrm{~h}$ at $180 \mathrm{rpm}, 30{ }^{\circ} \mathrm{C}$. Treatments were performed in triplicate. Growth of the functional bacterium was determined by measuring the absorbance of the culture supernatant at $600 \mathrm{~nm}$ using a Unicam UV9100visible spectrophotometer (Thermo Fisher Scientific, USA).

\section{Degradation assay and mechanisms analysis}

Exponentially growing functional bacterial strains were inoculated in mineral solution with $25 \mathrm{mg} / \mathrm{l}$ of atrazine and $1 \%$ yeast extract. Samples were collected after 3-day incubation at $30{ }^{\circ} \mathrm{C}$. For the bacterial isolates later designated as $\mathrm{C} 3$, samples were collected for $72 \mathrm{~h}$ with a 6-h interval. Atrazine and its catabolite were extracted as follows. Aliquots $(2 \mathrm{ml})$ of samples were extracted with $4 \mathrm{ml}$ of chloroform for three times. The total of $12 \mathrm{ml}$ organic phase was dried by volatilizing chloroform in vacuum and dissolved in $2 \mathrm{ml}$ mixture of methyl cyanide and $\mathrm{ddH}_{2} \mathrm{O}$ (1:1) for further analysis. High-performance liquid chromatography (HPLC) analyses were performed using an Agilent 1200 (USA), equipped with a Hypersil Gold C18 column (Thermo Fisher Scientific, USA, $4.6 \times 150 \mathrm{~mm}$ ). Eighty percent methyl cyanide and $20 \%$ water were applied as the mobile phase at a flow rate of $1 \mathrm{ml} / \mathrm{min}$ using the absorbance wavelength of $230 \mathrm{~nm}$. The biodegradation products of atrazine were detected by the LCQ Fleet mass spectrometer (Thermo Fisher Scientific, USA) coupled with HPLC.

Atrazine-degradation-related gene was detected by PCR amplification with primers specific for $a t z A, a t z D, t r z \mathrm{~N}$, and $t_{r z} \mathrm{D}$ (de Souza et al. 1998; Mulbry et al. 2002; Rousseaux 
Table 1 Atrazine-degrading bacterial isolates and their degradation efficiency

\begin{tabular}{llllc}
\hline Isolates & Phylum & Closed cultured organism (GenBank accession no.) & Identity (\%) & Degradation efficiency (\%) \\
\hline C1 & Actinobacteria & Streptomyces tricolor HBUM174995 (FJ532400.1) & 98 & 42.7 \\
C2 & Proteobacteria & Burkholderia cenocepacia MC0-3 (CP000960) & 97 & 43.0 \\
C3 & Actinobacteria & Arthrobacter sp. SD41 (KC415036) & 99 & 100 \\
E1 & Proteobacteria & Variovorax sp. S15 (HE662647.1) & 98 & 40.4 \\
E3 & Proteobacteria & Sphingobium sp. YJ2 (HQ260908.1) & 97 & 26.6 \\
F1 & Actinobacteria & Rhodococcus opacus (DQ474758.1) & 98 & 45.6 \\
F3 & Actinobacteria & Streptomyces sp. NY05-11A (FJ546742.1) & 97 & 39.6 \\
\hline
\end{tabular}

et al. 2001; Topp et al. 2000). The PCR amplification was conducted in a $50 \mu \mathrm{l}$ reaction system which includes $37.8 \mu \mathrm{l}$ of sterilized distilled water, $5 \mu$ of $10 \times$ high-fidelity PCR buffer, $2 \mu \mathrm{MgSO}_{4}(50 \mathrm{mM}), 1 \mu \mathrm{l}$ of a mix of dNTP (2.5 mM each), $1 \mu \mathrm{l}$ of $100 \mu \mathrm{mM}$ of different primers, $0.2 \mu \mathrm{l}$ of Platinum ${ }^{\circledR}$ Taq DNA (Invitrogen Life Technologies, Carlsbad, CA, USA) and $2 \mu \mathrm{l}$ of template DNA (20 ng/ $\mu \mathrm{l})$. The PCR amplification was conducted as follows. A $5 \mathrm{~min}$ initial denaturing period at $97{ }^{\circ} \mathrm{C}$ was followed by 29 cycles at $92{ }^{\circ} \mathrm{C}$ for $30 \mathrm{~s}, 60{ }^{\circ} \mathrm{C}$ (for $a t z A$ and $a t z D$ ) and $55^{\circ} \mathrm{C}$ (for $\operatorname{trz} \mathrm{N}$ and $t r z \mathrm{D}$ ) for $2 \mathrm{~min}, 72^{\circ} \mathrm{C}$ for $90 \mathrm{~s}$, and a final extension of $72{ }^{\circ} \mathrm{C}$ for $30 \mathrm{~min}$. PCR products were detected by electrophoresis using $1 \%$ agarose gel. Amplicons were sequenced by Shanghai Life Technologies Biotechnology Co., Ltd. (Shanghai, China). Functional gene sequences were analyzed using the BLASTn tool at the NCBI website to aid in the selection of the closest reference sequences. Phylogenetic analyses were performed using the Mega 4 software package (Tamura et al. 2007), and sequences were aligned using the positional tree server with a data set containing the nearest relative matches. Trees were constructed using the neighbor-joining (Jukes-Cantor correction) algorithms. The robustness of the inferred tree topologies was evaluated after 1000 bootstrap replicates of the neighbor-joining data.

\section{Nucleotide sequence accession numbers}

The 16S rRNA gene sequences and atrazine-degrading functional gene of bacterial isolates newly determined in this work have been deposited in GenBank under accession numbers KR265339 (strain C1), KR265340 (strain C2), KR181961 (strain C3), KR265341 (strain E1), KR265342 (strain E3), KR265343 (strain F1), KR265344 (strain F3), and KR263873 (trz $\mathrm{N}$ gene).

\section{Results and discussion}

\section{Isolation and characterization of atrazine-degrading bacteria}

A total of seven bacterial strains capable of degrading atrazine were isolated from atrazine-contaminated soil. 16S
rRNA gene sequences indicated that these strains affiliated into different genera, including Streptomyces, Burkholderia, Arthrobacter, Variovorax, Sphingobium, and Rhodococcus. All these isolates showed high efficiency of degrading the herbicide, with values between 39.6 and $100 \%$ (Table 1). A bacterial strain, designated as $\mathrm{C} 3$, which showed significant high atrazine-degrading capability, ca. $100 \%$ degradation after 7-day enriching period, was chosen for further studies. After 48-h incubation on mineral agar plates, strain C3 forms circular, flat, and white colonies. Gram staining showed that $\mathrm{C} 3$ is a Gram-positive bacterial strain. $16 \mathrm{~S}$ rRNA gene sequence comparisons indicated that strain C3 shows a high similarity (99\%) to the previously isolated bacterium Arthrobacter sp. SD41 (gene bank accession number, KC415036), which affiliated into the phylum Actinobacterium. Based on the phenotypic characteristics and phylogenetic analysis, strain C3 was identified as Arthrobacter sp.. The genus Arthrobacter, widely distributed in soil, has been proven to be capable of degrading various organic compounds. A. crystallopoietes, isolated from dichromate-contaminated soil, could efficiently degrade hexavalent chromium, $\mathrm{Cr}(\mathrm{VI})$, by producing a periplasmic chromate reductase (Camargo et al. 2004). A novel bacterial strain, designated as Arthrobacter chlorophenolicus sp. nov., could grow on high concentrations (up to $350 \mathrm{ppm}$ ) of 4-chlorophenol (4-CP) and showed great potential of bioremediation of 4-CP (Westerberg et al. 2000). Bacteria in this genus have also been found to be able to remediate $p$-nitrophenol (PNP), 2-methyl, 2-ethyl, 2-hydroxypyridine, phenol, and cresol isomer (Labana et al. 2005; Kar et al. 1997; O’Loughlin et al. 1999). Here, a bacterium affiliated into the genus Arthrobacter was isolated from atrazine-contaminated crop field. The strain showed a high atrazine-degrading efficiency which could degrade $25 \mathrm{mg} / \mathrm{l}$ atrazine in $6 \mathrm{~h}$. Serial experiments with different concentrations of atrazine $(5,25,100,500 \mathrm{mg} / \mathrm{l})$ were set up in this study to investigate the capability of atrazine degradation by strain C3. The results indicated that strain C3 could grow and degrade atrazine in medium with up to $500 \mathrm{mg} / \mathrm{l}$ atrazine (data not shown). Previous studies have revealed that functional bacteria could tolerate high concentration of atrazine. A. nicotinovorans HIM, a atrazine- 


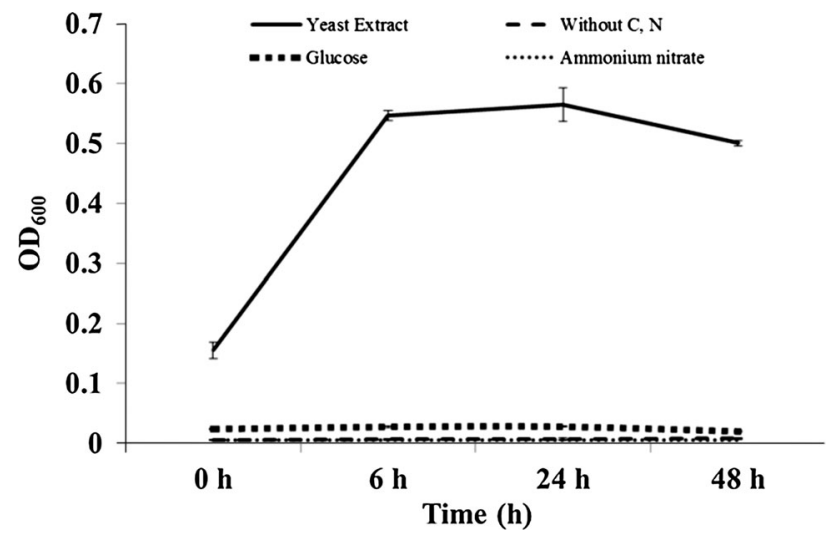

Fig. 1 Growth of the functional bacterium Arthrobacter sp. C3 in mineral solution amended with (solid line) yeast extract as both carbon and nitrogen sources; (dash dot line) glucose as carbon source; (short dot line) $\mathrm{NH}_{4} \mathrm{NO} 3$ as nitrogen source; (dash line) no additional carbon and nitrogen sources

degrading bacterium isolated from New Zealand, could grow in medium with $1000 \mathrm{ppm}$ atrazine (Aislabie et al. 2004). A. aurescens TC1 could grow in liquid medium with atrazine as the sole source of nitrogen, carbon, and energy, consuming up to $3000 \mathrm{mg}$ of atrazine per liter (Strong et al. 2002). All these evidence indicated that the genus Arthrobacter had a potential to be used in high-concentration atrazine-contaminated field.

\section{Nutrient effects on the growth of Arthrobacter sp. C3}

Exogenous carbon and nitrogen sources are both essential for the growth of the functional bacterium Arthrobacter sp.
C3. In the treatment (1), in which yeast extract was amended as both carbon and nitrogen sources, stationary phase could be attained in $6 \mathrm{~h}$, while no obvious growth was observed till the end of the 48-h incubation period in all of the other three treatments (Fig. 1). The degradation efficiency was not measured for the treatment (2), (3), and (4) since no growth of the bacteria was detected.

\section{Analysis of atrazine degradation and its catabolites}

HPLC was applied to detect atrazine and its catabolites. Atrazine was detected in the growth medium with addition of functional bacterium Arthrobacter sp. C3 at the beginning of the degradation assay $(0 \mathrm{~h})$. An obvious single peak was measured at the retention time of $2.20 \mathrm{~min}$ (Fig. 2). After 6-h incubation, the peak could not be detected any more; instead, a novel peak with retention time of 3.75 min was observed (Fig. 2). These samples were also analyzed by mass spectrum to characterize the atrazine and its catabolites in the medium with inoculation of strain C3. The molecular mass and fragmentation pattern indicated that the catabolite encoded with the two peaks was conducted by loss of $\mathrm{Cl}$ with 35.5 mass units and acquisition of $\mathrm{OH}$ with 17 mass units (Fig. 3). The catabolite was consistent with the structure of the first-step catabolite, hydroxyatrazine.

Four critical functional genes, atzA, atzD, $t r z \mathrm{~N}$, and $t r z \mathrm{D}$, involved in two key steps of bioremediation of atrazine were investigated to reveal the mechanism of atrazine degradation by strain $\mathrm{C} 3$. The gene $\operatorname{trz} \mathrm{N}$ was successfully amplified, while all the other three genes were not detected.

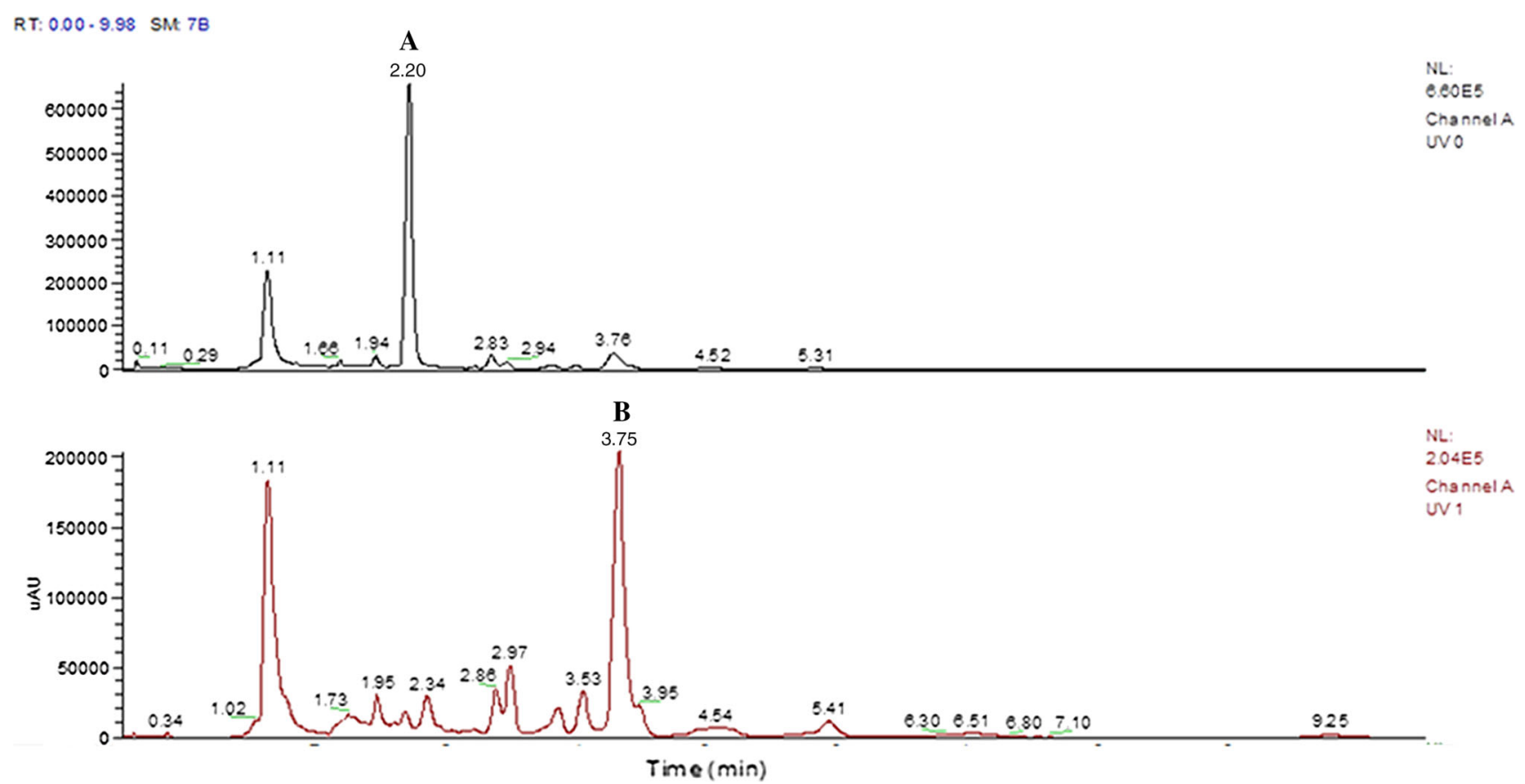

Fig. 2 Chromatograms of atrazine and its metabolic products after 0 and $6 \mathrm{~h}$ incubation with Arthrobacter sp. C3. The peak $A$ indicated atrazine with a retention time of $2.20 \mathrm{~min}$, while the peak $B$ indicated a catabolite with a retention time of $3.75 \mathrm{~min}$ 

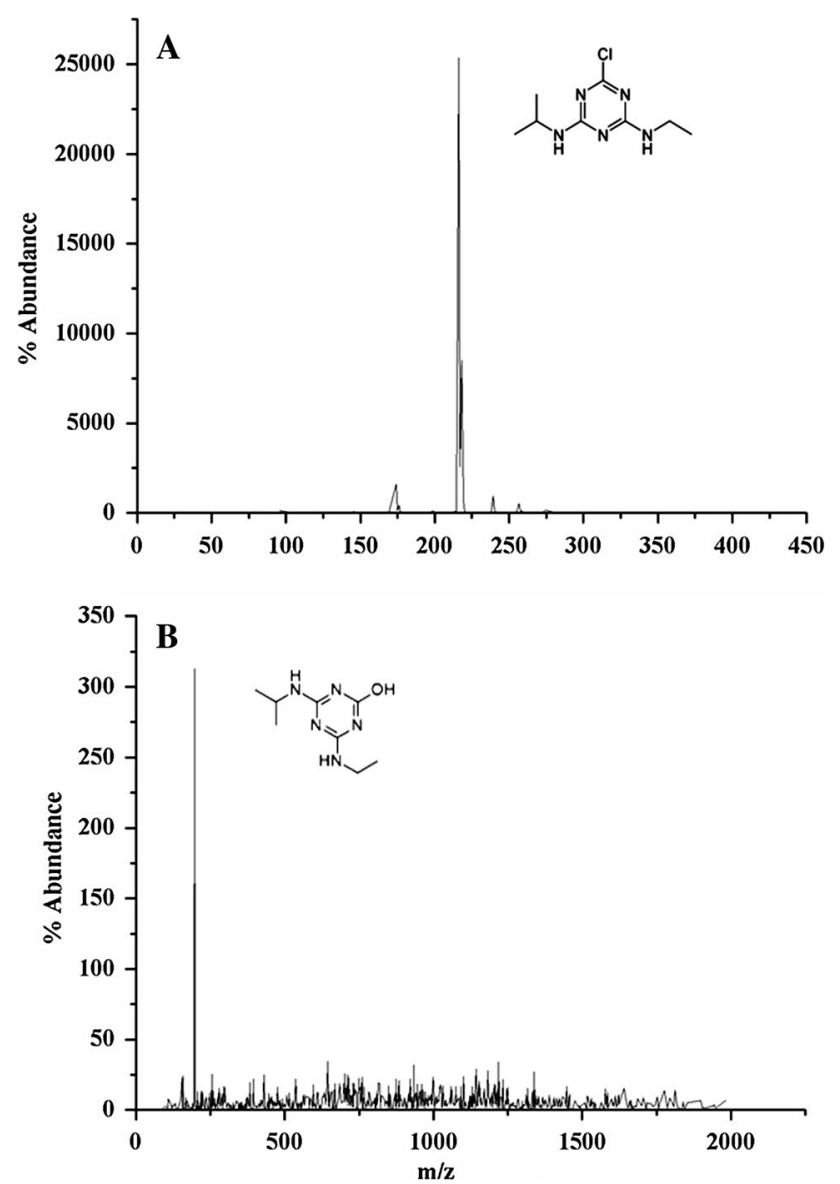

Fig. 3 Mass spectra of atrazine and its metabolic products obtained from culture extracts of strain $\mathrm{C} 3$ incubated in the presence of the herbicide after (a) 0-h incubation and (b) 6-h incubation. The mass spectrum of the transformation product is consistent with the hydroxytriazine structure (b)

PCR amplicon of $\operatorname{trz} \mathrm{N}$ gene was then sequenced which resulted a 1312-bp sequence. Results of BLASTn indicated that the sequence has a high similarity (99\%) to the identified Arthrobacter sp. AD30 triazine hydrolase $(\operatorname{trz} \mathrm{N})$ gene. Phylogenetic analysis indicated that $t r z \mathrm{~N}$ gene of the newly isolated bacterial strain C3 grouped together with AD30 trz $\mathrm{N}$ gene, and had high similarities to all identified $t_{r z} \mathrm{~N}$ gene from different microorganisms.

The pathway of atrazine degradation has been well characterized. Genes including atz group $(a t z \mathrm{~A}, a t z \mathrm{~B}, a t z \mathrm{C}$, $a t z \mathrm{D}, a t z \mathrm{E}, a t z \mathrm{~F})$ and $t r z$ group $(t r z \mathrm{~N}, t r z \mathrm{D}, t r z \mathrm{E}, t r z \mathrm{~F})$ were acknowledged to be involved in the atrazine-catabolic pathway. atzA and $t r z \mathrm{~N}$ encoded with atrazine chlorohydrolase which catalyze atrazine to hydroxyatrazine in the first step of atrazine degradation. $a t z \mathrm{D}$ and $t r z \mathrm{D}$ were involved in the ring cleavage by expressing cyanuric acid amidohydrolase and catalyzing cyanuric acid to biuret. These were four key genes used for revealing the taxonomic and functional diversity of atrazine-degrading bacterial communities (Udiković-Kolić et al. 2010; Martinez et al. 2001; Li et al. 2008). These genes could also be used as gene indicators to distinguish different atrazine-degrading pathways conducted by the two different functional groups. Here, $a t z \mathrm{~A}, a t z \mathrm{D}, \operatorname{tr} z \mathrm{~N}$, and $t r z \mathrm{D}$ were applied to investigate the atrazine-degrading mechanism of functional bacterium Arthrobacter sp. C3. Among the four functional genes, only $t r z \mathrm{~N}$ was successfully amplified. The sequence of $\operatorname{trz} \mathrm{N}$ amplicon was consistent with that previously found in atrazine-degrading bacteria Arthrobacter, Pseudomonas, and Nocardioides isolates (Sajjaphan et al. 2004; Mongodin et al. 2006; Yamazaki et al. 2008; Topp et al. 2000). By the expression of the enzyme trzN, strain C 3 could successfully degrade atrazine to hydroxyatrazine, a chemical without phytotoxic activity. This was consistent with the degradation assay by HPLC-MS, in which only hydroxyatrazine was detected as the catabolite of atrazine degradation. Taken together, our results indicated that the strain Arthrobacter sp. C3 degraded atrazine by a hydrolytic dechlorination reaction, which is acknowledged to initiate atrazine degradation. The mineralization of atrazine could be completed by a single bacterial strain which has an integrated atrazine-metabolic pathway, or by a microbial consortium with different functional bacteria. Transformation into hydroxyatrazine by dechlorination was the key process for biodegradation and obligatory for complete mineralization of atrazine. Smith et al. (2005) found that the bacterial consortium including Agrobacterium tumefaciens, Caulobacter crescentus, Pseudomonas putida, Sphingomonas yaniokuyae, Nocardia sp., Rhizobium sp., Flavobacterium oryzihabitans, and Variovorax paradoxus could effectively mineralize atrazine. But the enrichment culture was destabilized by loss of Nocardia sp., which was responsible for dechlorination, and no longer able to degrade atrazine. Topp et al. (2000) also found that six out of their 14 atrazine-degrading isolates could not mineralize atrazine but produce a product coeluted with hydroxyatrzine. Here, the strain C3 could dechlorinate atrazine, the key process of detoxification. It was supposed that other functional bacteria would attend the residual process of mineralization of atrazine.

\section{Conclusion}

Overall, a functional bacterium C3, affiliated into the genus Arthrobacter in the phylum Actinobacteria, was successfully isolated in this study. The bacterium could dechlorinate atrazine to a non-phytotoxic compound, hydroxyatrzine. $t r z \mathrm{~N}$ gene the functional gene participating in the dechlorinating process of the first step of atrazine degradation was successfully amplified. Our results suggested that strain $\mathrm{C} 3$ could not mineralize the herbicide, but could detoxify atrazine to hydroxyatrzine. This study 
opened an insight of bioremediation of atrazine by functional bacterium Arthrobacter sp. C3. The functional isolate Arthrobacter sp. $\mathrm{C} 3$ is believed to have a great potential to be used in bioremediation of atrazine in the field. Further studies will be conducted by applying the functional bacterium in indigenous bioremediation.

Acknowledgments Fundings for this research were provided by the Hundred Talents Program of Chinese Academy of Sciences awarded to Xiaoke Hu (No. 1191100502), the Key Research Program of the Chinese Academy of Sciences (No. KZZD-EW-14), National Natural Science Foundation of China (No. 41376138) and Science and Technology Program of Shandong Province (No. 2013GHY11534).

\section{References}

Aislabie J, Hunter D, Ryburn J, Fraser R, Northcott GL, Di HJ (2004) Atrazine mineralisation rates in New Zealand soils are affected by time since atrazine exposure. Soil Res 42(7):783-792

Bouquard C, Ouazzani J, Prome J, Michel-Briand Y, Plesiat P (1997) Dechlorination of atrazine by a Rhizobium sp. isolate. Appl Environ Microbiol 63(3):862-866

Cai B, Han Y, Liu B, Ren Y, Jiang S (2003) Isolation and characterization of an atrazine-degrading bacterium from industrial wastewater in China. Lett Appl Microbiol 36(5):272-276

Camargo FAO, Bento FM, Okeke BC, Frankenberger WT (2004) Hexavalent chromium reduction by an actinomycete, Arthrobacter crystallopoietes ES 32. Biol Trace Elem Res 97(2):183-194

de Souza ML, Seffernick J, Martinez B, Sadowsky MJ, Wackett LP (1998) The atrazine catabolism genes atzABC are widespread and highly conserved. J Bacteriol 180(7):1951-1954

Enticknap JJ, Kelly M, Peraud O, Hill RT (2006) Characterization of a culturable alphaproteobacterial symbiont common to many marine sponges and evidence for vertical transmission via sponge larvae. Appl Environ Microbiol 72(5):3724-3732

Fernández L, Valverde C, Gómez M (2013) Isolation and characterization of atrazine-degrading Arthrobacter sp. strains from Argentine agricultural soils. Ann Microbiol 63(1):207-214

Head IM, Jones DM, Roling WFM (2006) Marine microorganisms make a meal of oil. Nat Rev Microbiol 4(3):173-182

Kar S, Swaminathan T, Baradarajan A (1997) Biodegradation of phenol and cresol isomer mixtures by Arthrobacter. World J Microbiol Biotechnol 13(6):659-663

Labana S, Singh V, Basu A, Pandey G, Jain RK (2005) A microcosm study on bioremediation of $p$-nitrophenol-contaminated soil using Arthrobacter protophormiae RKJ100. Appl Microbiol Biotechnol 68(3):417-424

Li Q, Li Y, Zhu X, Cai B (2008) Isolation and characterization of atrazine-degrading Arthrobacter sp. AD26 and use of this strain in bioremediation of contaminated soil. $\mathrm{J}$ Environ Sci 20(10): $1226-1230$

Louisa Wessels P (2010) Review: in situ and bioremediation of organic pollutants in aquatic sediments. J Hazard Mater $177(1-3): 81-89$

Martinez B, Tomkins J, Wackett LP, Wing R, Sadowsky MJ (2001) Complete nucleotide sequence and organization of the atrazine catabolic plasmid pADP-1 from Pseudomonas sp. strain ADP. J Bacteriol 183(19):5684-5697

Mongodin EF, Shapir N, Daugherty SC, DeBoy RT, Emerson JB, Shvartzbeyn A, Radune D, Vamathevan J, Rigg F, Grinberg V, Khouri H, Wackett LP, Nelson KE, Sadowsky MJ (2006) Secrets of soil survival revealed by the genome sequence of Arthrobacter aurescens TC1. PLoS Genet 2(12):2094-2106
Mulbry WW, Zhu H, Nour SM, Topp E (2002) The triazine hydrolase gene $t r z \mathrm{~N}$ from Nocardioides sp. strain C190: cloning and construction of gene-specific primers. FEMS Microbiol Lett 206(1):75-79

O'Loughlin E, Sims G, Traina S (1999) Biodegradation of 2-methyl, 2-ethyl, and 2-hydroxypyridine by an Arthrobacter sp. isolated from subsurface sediment. Biodegradation 10(2):93-104

Rousseaux S, Hartmann A, Soulas G (2001) Isolation and characterisation of new Gram-negative and Gram-positive atrazine degrading bacteria from different French soils. FEMS Microbiol Ecol 36(2-3):211-222

Sajjaphan K, Shapir N, Wackett LP, Palmer M, Blackmon B, Tomkins J, Sadowsky MJ (2004) Arthrobacter aurescens TC1 atrazine catabolism genes $t r z \mathrm{~N}, a t z \mathrm{~B}$, and $a t z \mathrm{C}$ are linked on a 160-Kilobase region and are functional in Escherichia coli. Appl Environ Microbiol 70(7):4402-4407

Singh P, Suri CR, Cameotra SS (2004) Isolation of a member of Acinetobacter species involved in atrazine degradation. Biochem Biophys Res Commun 317(3):697-702

Smith D, Alvey S, Crowley DE (2005) Cooperative catabolic pathways within anatrazine-degrading enrichment culture isolated from soil. FEMS Microbiol Ecol 53(2):265-273

Strong LC, Rosendahl C, Johnson G, Sadowsky MJ, Wackett LP (2002) Arthrobacter aurescens TC1 metabolizes diverse $s$-triazine ring compounds. Appl Environ Microbiol 68(12):5973-5980

Tamura K, Dudley J, Nei M, Kumar S (2007) MEGA4: molecular evolutionary genetics analysis (MEGA) software version 4.0. Mol Biol Evol 24(8):1596-1599

Topp E, Zhu H, Nour SM, Houot S, Lewis M, Cuppels D (2000) Characterization of an atrazine-degrading Pseudaminobacter sp. isolated from Canadian and French agricultural soils. Appl Environ Microbiol 66(7):2773-2782

Tortella GR, Mella-Herrera RA, Sousa DZ, Rubilar O, Acuña JJ, Briceño G, Diez MC (2013) Atrazine dissipation and its impact on the microbial communities and community level physiological profiles in a microcosm simulating the biomixture of onfarm biopurification system. J Hazard Mater 260:459-467

Udiković-Kolić N, Hršak D, Devers M, Klepac-Ceraj V, Petrić I, Martin-Laurent F (2010) Taxonomic and functional diversity of atrazine-degrading bacterial communities enriched from agrochemical factory soil. J Appl Microbiol 109(1):355-367

Wang H, Su JQ, Zheng XW, Tian Y, Xiong XJ, Zheng TL (2009a) Bacterial decolorization and degradation of the reactive dye Reactive Red 180 by Citrobacter sp. CK3. Int Biodeterior Biodegrad 63(4):395-399

Wang H, Zheng XW, Su JQ, Tian Y, Xiong XJ, Zheng TL (2009b) Biological decolorization of the reactive dyes Reactive Black 5 by a novel isolated bacterial strain Enterobacter sp. EC3. J Hazard Mater 171(1-3):654-659

Westerberg K, Elväng AM, Stackebrandt E, Jansson JK (2000) Arthrobacter chlorophenolicus sp. nov., a new species capable of degrading high concentrations of 4-chlorophenol. Int J Syst Evol Microbiol 50(6):2083-2092

Yamazaki K, Fujii K, Iwasaki A, Takagi K, Satsuma K, Harada N, Uchimura $\mathrm{T}$ (2008) Different substrate specificities of two triazine hydrolases (TrzNs) from Nocardioides species. FEMS Microbiol Lett 286(2):171-177

Yang C, Li Y, Zhang K, Wang X, Ma C, Tang H, Xu P (2010) Atrazine degradation by a simple consortium of Klebsiella sp. $\mathrm{A} 1$ and Comamonas sp. A2 in nitrogen enriched medium. Biodegradation 21(1):97-105

Yanze-Kontchou C, Gschwind N (1994) Mineralization of the herbicide atrazine as a carbon source by a Pseudomonas strain. Appl Environ Microbiol 60(12):4297-4302 